\title{
Whole body MR-PET: a new internal dosimetry method for radiation transport calculation from biokinetic model data
}

\author{
Ana Nunes ${ }^{1 *}$, Francisco Alves ${ }^{1,2}$, Miguel Patrício ${ }^{3}$ \\ From PSMR14: 3rd Conference in PET/MR and SPECT/MR \\ Kos Island, Greece. 19-21 May 2014
}

${ }^{1}$ Institute of Nuclear Sciences Applied to Health (ICNAS), University of Coimbra, Portugal
In order to ensure the safe usage of new radiopharmaceuticals in Positron Emission Tomography (PET), it is necessary to quantify the doses delivered to the organs and tissues within the patients' bodies. A framework that allows estimating the dose delivered by PET has been established by the MIRD Committee [1,2] and ICRP [3]. Although this covers the most important terms and concepts in Internal Radiation Dosimetry (IRD), it does not provide a detailed guide to assist in the development of a full dosimetric study. We discuss the development, implementation, assessment and validation of an accurate method for IRD studies of PET radiotracers.

We undertook a systematic review $[4,5]$ of previous PET dosimetry studies to identify the current biodistribution data acquisition and analysis methodologies. The methods reported were compared, particularly in terms of the collection of biokinetic data and the estimation of dose results. As a wide heterogeneity of approaches was found, it is important to assessthe impact of different choices in the internal dose calculation protocol. In particular, we quantify the variation in internal dose with different assumptions regarding organ activity uptake - namely, instantaneous uptake vs. different methods to extrapolate to zero activity at time zero. For that purpose, whole-body ${ }^{11} \mathrm{C}$-Raclopride PET data have been acquired and the corresponding internal doses estimated.

\footnotetext{
Authors' details

${ }^{1}$ Institute of Nuclear Sciences Applied to Health (ICNAS), University of Coimbra, Portugal. ${ }^{2}$ College of Health Technology - Polytechnic Institute of Coimbra, Portugal. ${ }^{3}$ Laboratory of Biostatistics and Medical Informatics, IBILI Faculty of Medicine, University of Coimbra, Portugal.

Published: 29 July 2014

References

1. Siegel JA, Thomas SR, Stubbs JB, Stabin MG, Hays MT, Koral KF, Robertson JS, Howel RWI, Wessels BW, Fisher DR: MIRD pamphlet no. 16: techniques for quantitative radiopharmaceutical biodistribution data acquisition and analysis for use in human radiation dose estimates. J. Nucl. Med. 1999, 40(2):37-61.

2. Bolch WE, Eckerman KF, Sgouros G, Thomas SR: MIRD pamphlet no. 21: a generalized schema for radiopharmaceutical dosimetry-standardization of nomenclature. J. NuCl. Med. 2009, 50:477-484.

3. ICRP: The 2007 Recommendations of the International Commission on Radiological Protection. In Ann. ICRP. Volume 37. ICRP Publication 103; 2007:(2.4):2[http://www.icrp.org/docs/ICRP_Publication_103-Annals_of_the_ICRP_37(2-4)Free_extract.pdf].
}

(c) 2014 Nunes et al; licensee Springer This is an Open Access article distributed under the terms of the Creative Commons Attribution License (http://creativecommons.org/licenses/by/4.0), which permits unrestricted use, distribution, and reproduction in any medium, provided the original work is properly cited. 
4. Liberati A, Altman DG, Tetzlaff J, Mulrow C, Gøtzsche PC, loannidis JP, Clarke M, Devereaux PJ, Kleijnen J, Moher D: The PRISMA statement for reporting systematic reviews and meta-analyses of studies that evaluate health care interventions: explanation and elaboration. Ann. Intern. Med. 2009, 151(4).

5. Moher D, Liberat A, Tetzlaff J, Altman DG: Preferred reporting items for systematic reviews and meta-analyses: the PRISMA statement. Ann. Intern. Med. 2009, 151:264-269.

doi:10.1186/2197-7364-1-S1-A78

Cite this article as: Nunes et al:: Whole body MR-PET: a new internal dosimetry method for radiation transport calculation from biokinetic model data. EJNMMI Physics 2014 1(Suppl 1):A78.

\section{Submit your manuscript to a SpringerOpen ${ }^{\circ}$} journal and benefit from:

- Convenient online submission

- Rigorous peer review

- Immediate publication on acceptance

- Open access: articles freely available online

- High visibility within the field

- Retaining the copyright to your article

Submit your next manuscript at $\boldsymbol{s p r i n g e r o p e n . c o m ~}$ 